\title{
クリーンルーム評価における逐次検定法の特性 SEQUENTIAL SAMPLING FOR EVALUATION OF LOW CONCENTRATION IN CLEANROOM
}

\author{
藤 井 修二*1, 湯 浅 和 博*2, 今井田尚文*3, 西 村 直 也*4, 田村 一*5 \\ Shuji FUJII, Kazuhiro YUASA, Naofumi IMAIDA, Naoya NISHIMURA \\ and Hajime TAMURA
}

\footnotetext{
The sequential sampling is one of the evaluation methods for high class cleanroom to reduce sampling duration.

In this paper, sequential sampling is simulated by Monte Carlo method and characterized in the case of different concentration and its distribution of particles. Two types of model are considered as sequential samplings. One is the particle arrival model and the other is the constant unit sampling model.

These models are applied to simulate particle concentration.

Keywords : cleanroom, sequential sampling, monte carlo method クリーンルーム, 逐次検定法, モンテカルロ法
}

\section{1.はじめに}

高清浄度クリーンルームにおいては、清浄度評価の指 標となる浮遊微粒子の濃度が極めて低く、平均濃度から 統計的に清浄度を評価する従来の評価方法においては、 統計的評価に十分な粒子数を得るために大量のサンプリ ング空気量を必要とし、莫大な計剆時間を要するという 問題点が生じている。

日本では泉本らが、高清浄度クリーンルーム評価にお いて、確率統計的処理をすることにより清净度の推定を 行うほか、計測時間の短縮に有効な方法として逐次検定 法を提案し、評価線図を作成した ${ }^{32}$ 。現在、逐次検定法 は日本工業規格(JIS B 9920)六に採用されている。また 米国連邦規格（FED-STD-209）においても1992年に209Dから 209Eに改訂されるにおよび、クーパーらの提案による逐 次検定線図をもとにした、逐次検定法が導入されている しかし、両者いずれにおいても対象空間の濃度分布との 対応や、評価特性に関する検跴は十分ではないと考えら
れる。

本研究の目的は、モンテカルロ法を用いたシミュレー ションにより、逐次検定法の清浄度評価特性を把握する 点にある。本報では、まず、逐次検定法のシミュレーシ ヨンモデルを作成し、モデルとしての評価特性の検討を 行った。次に、クリーンルームの清浄度評価に逐次検定 法を用いた場合の、評価対象空間の平均粒子濃度およひ その分布形に対する特性について検討した。

\section{2. 逐次梌定法}

図一 1 に逐次険定法の評価線図を示す。評価線図は横 軸にサンプリング回数、維軸に柆子の累積カウント数を とり、線に区切られた「合格」、「不合格」及ひ「サン プリング続行」の3つの領域からなっている。逐次検定 法では、サンプリングこと*1の柆子計数値の累榡数をプ ロットし座標が合格（不合格）領域に入った時点で「合
本論文は文献 3），4）を修正・加筆したものである

*1 東京工業大学工学部建築学科 助教授. 工博

*2 東京工業大学工学部建築学科 助手. 工博

*3 清水建設 (株) 設計本部・ I修

*4 (株) 大林組東京本社設計本部・工修

*5 (株) テクノ菱和技術本部
Assoc. Prof., Tokyo Institute of Technology, Dr. Eng. Research Assoc., Tokyo Institute of Technology, Dr. Eng. Shimizu Corp., M. Eng. Obayashi Corp., M. Eng. Techno Ryowa Ltd. 
格（不合格）」の判定を下す。どちらの領域にも入らず 計数值が10以上に達した場合は判定不能となる。

信頼区間法では、観測值に対するポアンン分布の上側 信頼限界及び下側信頼限界によって、評価線図における 領域の境界が決定される。一方、クーパーらによって提 案されているワルドミニマックス法においては、ワルド の理論により 2 本の直線となる境界線が決定される。5

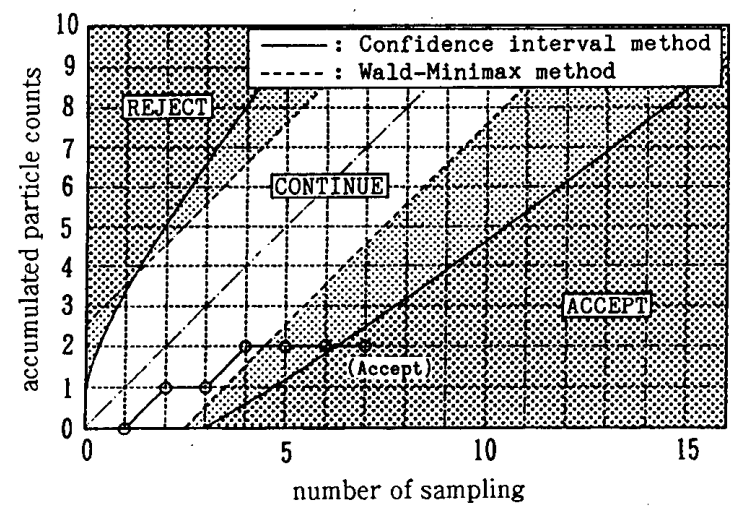

図一1 逐次検定法の評価線図

* 11 1サンプリング量はクラス別上限許容粒子数 $\left(\right.$ 個 $\left./ \mathrm{m}^{3}\right)$ に対して1(個/回)の粒子が検出されると期待される值 で表される。

例元ば対象粒径 $0.1 \mu \mathrm{m}$ のクラス 1 は上限許容粒子 数は $10^{1}\left(\right.$ 個 $\left./ \mathrm{m}^{3}\right)$ であるので 1 サンプリング量は 1 (個/回) $/ 10^{3}\left(\right.$ 個 $\left./ \mathrm{m}^{3}\right)=0.1\left(\mathrm{~m}^{3} /\right.$ 回 $)$ となる。

3. モンテカルロ法のシミュレーションモテル

粒子計数器に検出される粒子の到着モデルとして、図 一 2 に示すように一定時間到着粒子数モテルと粒子到着 間時間モデルを検討した。一定時間到着粒子数モデルは 一定時間における一定体積のサンプリング空気中に検出 される粒子数を表現する離散分布型モテルであり、一方 粒子到着間時間モデルは、2つの粒子が検出される時間 間隔を表現する連続分布型モデである。

本研究においては、空間の粒子濃度が時系列的に変化 しない場合、粒子計数值は平均濃度によって定まるポア ソン分布に従うと仮定している。事象がポアソン分布に 従う場合、事象が起こる時間間隔は指数分布に従う。

図一 3 に、粒子到着間時間に対して設定した分布の確 率密度関数を示す。アーラン分布をガンマ関数により拡 張したもので、パラメータ $\mathrm{k}$ が正整数の時アーラン分布 に一致し、 $\mathrm{k}=1$ の時指数分布に一致する。アーラン分 布の変動係数は $1 / \sqrt{\mathrm{k}}$ で与えられ、 $\mathrm{k}$ を大きくする規 則的な到着、 $\mathrm{k}=1$ でポアソン（ランダム）到着を表現

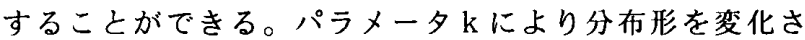
せることとした。

シミュレーションに用いる算術乱数は表 -1 に示す乗 算型合同法の線形漸化式により発生させた。初期値 $X_{0}$ a) consatant unit sampling model

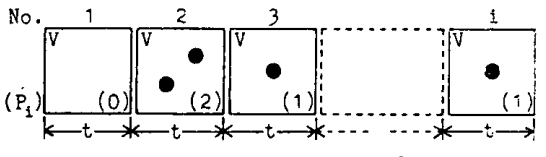

- : single particle

$P_{i}$ :particle number at $i-t h$ sampling $t$ : 1 -th sampling time(min ${ }_{j}$ const.) $V$ :i-th sampling volume $\left(\mathrm{m}^{3}\right.$; const.) $v$ :sample flow rate $\left(\mathrm{m}^{3} / \mathrm{min}\right)$
$\mathrm{V}=\mathrm{vt}$

$C_{i}:$ accumulated particle concentration at 1 -th sampling $\left(\mathrm{p} / \mathrm{m}^{3}\right)$ $\mathrm{C}_{i}=\mathrm{P}_{1} /\left(\mathrm{V}_{i}\right)$

b) particle arrival model

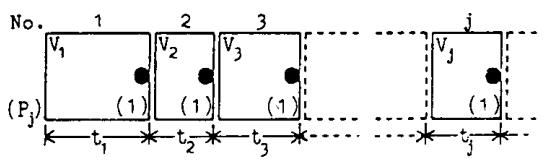

$t_{j}$ interval time between $j-1$ and $j$-th particle arrival(win)

$v_{j}$ : sampling alr volume for $t_{j}\left(m^{3}\right)$

$v_{j}=v t_{j}$

$c_{j}$ :accumblated particle concentration at $j$-th particle arrival $\left(p / m^{3}\right)$ $c_{j}=j / v_{j}$

図-2 一定時間粒子到着数モデルと粒子到着間時間モデル

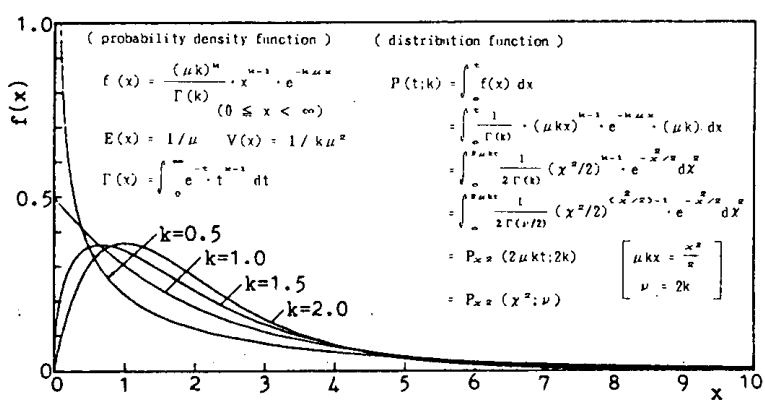

図-3 粒子到着間時間分布の確率密度関数

表 -1 一様疑似乱数の発生方法

$$
\begin{aligned}
& \text { (congruential method) } \\
& \begin{array}{l}
\mathrm{X}_{\mathbf{1}}=\mathrm{C} \cdot \mathrm{X}_{\mathbf{i - 1}} \quad(\bmod 1) \\
\mathrm{C}=10011 \\
\mathrm{X}_{\mathbf{0}}=.53952704
\end{array}
\end{aligned}
$$

及び係数 C を設定して乱数列を作成し、頻度検定、系 列相関検定、連の検定により最適な一様疑似乱数列を選 定した。

一様疑似乱数を、逆関数法により粒子到着間時間の分 布形に従う乱数に変換する（粒子到着間時間モデルに対 応する）。図 -4 は、その変換した乱数列の頻度分布を $\mathrm{k}=0.5 ， 1.0 ， 1.5 ， 2.0$ に対して示したもので、確率密 度関数によく一致していることが確認できる。さらにこ の乱数を、一定時間に検出される粒子数の分布に従う乱 数へと変換し（一定時間粒子到着数モデとなる）、こ 
の乱数を用いて逐次検定をシミュレートを行い、合格、 不合格及び測定不能の各判定回数及び判定所要時間を結 果として出力する。
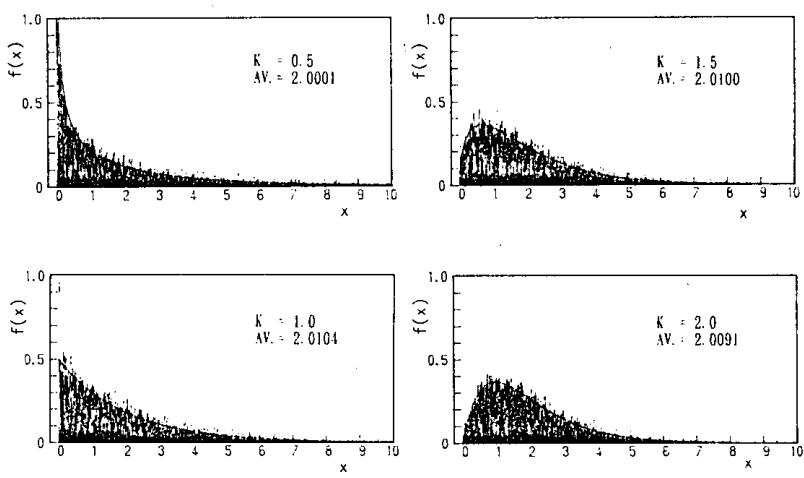

困-4 乱数の頻度分布

\section{4.一定時間柆子到着数モデルと柆子到着間時間 モデル}

シミュレーションモデルとしての特性を把握すること を目的に、一定時間粒子到着数モテルと粒子到着間時間 モデにより逐次検定法のシミュレーションを行った。 分布形についてはポアソン分布と指数分布を設定した。 なお本報で示した各図表は、クラス 1 、粒子計数器の吸 引流量 $100 \ell / \mathrm{min}$ 場合を表したものであるが、判定ま での平均所要時間及び濃度の軸に対し表 -2 に示す係数 を乗じることによりクラス $2 \sim 4$ に対応し、また実際の 時間単位：分に変換することができる。

平均到着粒子濃度 (以下、平均濃度) に対する各判定確 率を図 -5 に、また平均判定所要時間を図 -6 に示す。 粒子到着間時間モデルは一定時間粒子到着数モデルに比 へて左寄り、すなわち不合格寄りの判定となっており、 また平均判定所要時間については、特にクラス基準より 低濃度において差が大きくなっている。これは同じ事象 を表現する場合でも、粒子到着間時間モデは一定時間 粒子到着数モデルに比へ、評価線図において左寄りの座 標を通るためと考えられる。

以上の結果から、実際の逐次検定のサンプリング法と 一致する一定時間粒子到着数モデルを以降のシミュレー ションに用いることとした。

\section{表一 2 時間係数亡粒子灌度係数}

- for time -
$\mathrm{A}=\frac{10^{3}}{\mathrm{~S} \mathrm{~V} \cdot 10^{\mathrm{CL}}} \quad \mathrm{B}=10^{(\mathrm{CL}-1)}$
$\mathrm{SV}:$ air flow rate $(\ell / \mathrm{min})$
$\mathrm{C} \mathrm{L}:$ cleanliness class

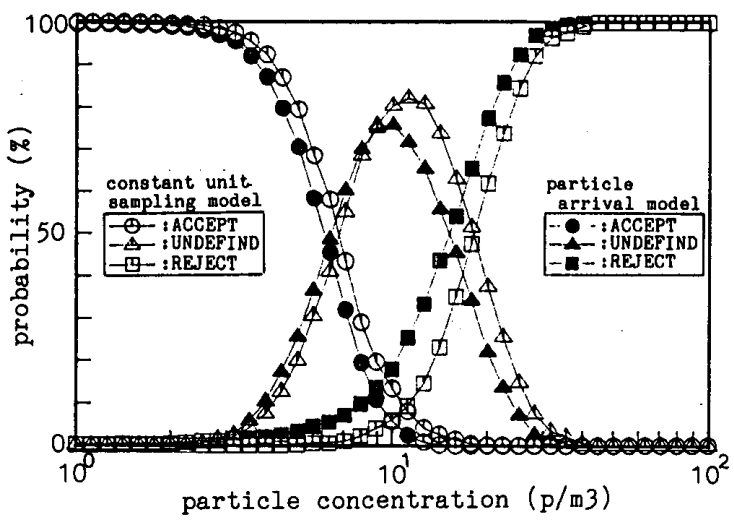

囯-5 平均濃度に対する各判定の確率

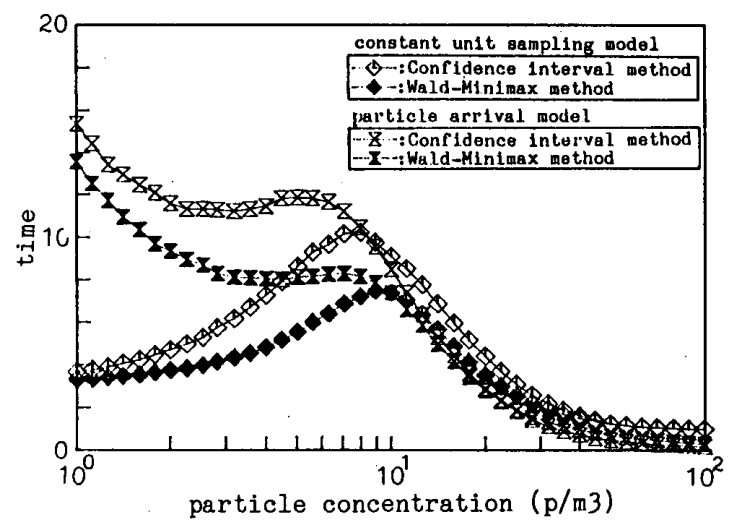

园-6 平均濃度に対する平均判定所要時間

\section{5 . 信頼区間法とワルドミニマックス法}

信頼区間法とワルドミニマックス法について、清净度 クラスのクラス 1 を対象として、平均濃度を $10^{\circ} \sim 10^{2}$

（個 $/ \mathrm{m}^{3}$ ）まで40段階、分布形のパラメーター $\mathrm{k}$ を $0.1 \sim$ 2.0まで20段階に変化させて、各1000回のシミュレーシ ヨンを行った。

図 -7 に平均濃度及びその分布形に対する各判定の確 率、平均判定所要時間を示す。両検定法とも $\mathrm{k}$ 值の增加 に伴い判定不能の確率が增加し、その傾向は基準濃度付 近で特に顕著であり、それに伴って判定所要時間も長く なっている。

また、図 -8 に平均濃度に対する各判定の確率を分布 形のパラメーター $\mathrm{k}=1$ に対して示す。信頼区間法は判 定力が低く、基準濃度付近で約 $80 \%$ の確率で判定不能と なっており判定所要時間が相対的に長くなっている。ワ ルド法は、クラス基準以上の平均濃度において合格判定 の確率が30\%を越えているのに対して、信頼区間法は10 \%以下と安全側の判定を下すことがわかる。

$95 \%$ の確率で合格と判定される平均濃度は、 $\mathrm{k}=1$ の とき信頼区間法で3.7(個 $\left./ \mathrm{m}^{3}\right)$ ワルド法で4.7(個/ $\left.\mathrm{m}^{3}\right)$ であり、 $\mathrm{k}$ 值が小さくなり粒子到着が不規則になると急 
激に低くなる傾向にある。不合格判定では、信頼区間法 で26.9(個/ $\left.\mathrm{m}^{3}\right)$ ワルド法で20.2(個/ $\left.\mathrm{m}^{3}\right)$ で $\mathrm{k}$ 值による 変化はあまりない。
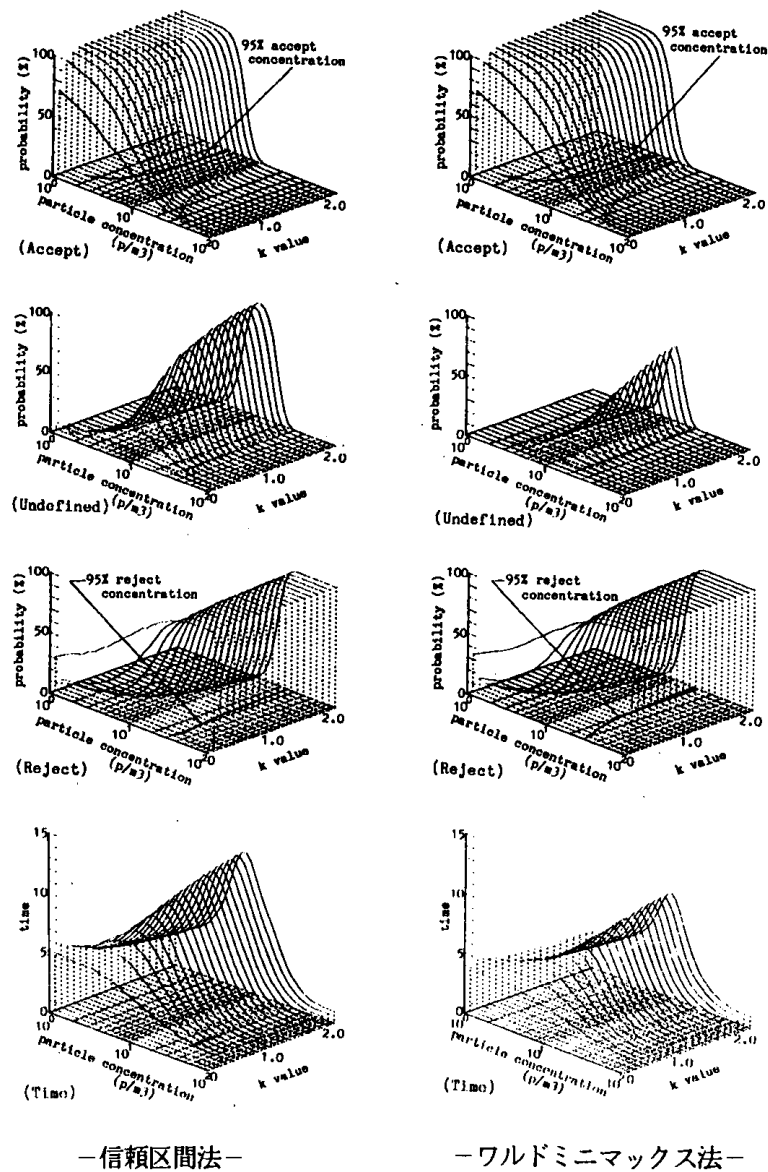

一信頼区間法一

図一7 平均濃度および分布形に対する判定確率と平均所要時間

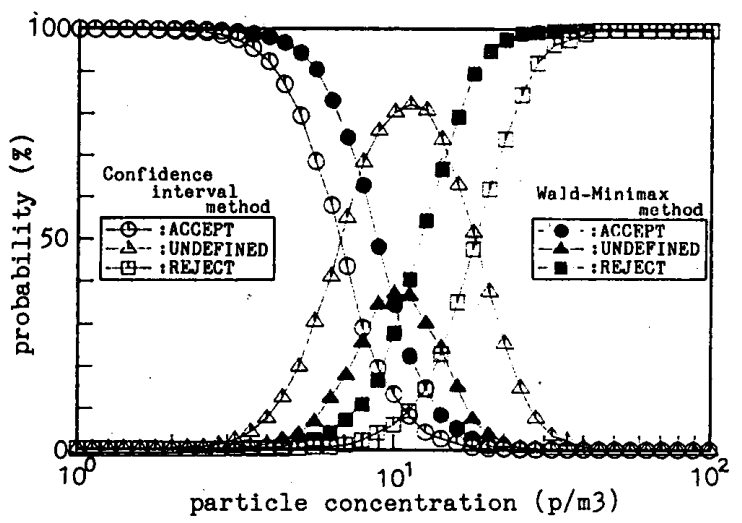

図-8 平均湮度に対する各判定の確率 $(\mathrm{k}=1)$

\section{6. 逐次検定法による各湘定点及び空阅全体 の棓価}

図－9に、J I S に規定されている信頼区間法による
逐次検定の評価手順を、また、図ー10にクーパーらによ り提案されているワルド法を変形した逐次検定評価線図 を示す（以下ワルド応用法とする）6》。 J I Sでは 2 回 を限度に逐次検定を行い、クラスと対象粒径により決め られる最小サンプリング量（クラス $1 \cdot$ 対象粒径0.1 $\mu \mathrm{m}$ 以上の場合 $\left.2,000 \times 10^{-3} \mathrm{~m}^{3}\right)$ の 3 倍の空気量をサンプリ ングし、計数值の平均濃度と上限濃度に 0.6 をかけた值 と比較して判定を行う。ワルド応用法は、最大カウント 数20を上限値として設定している。

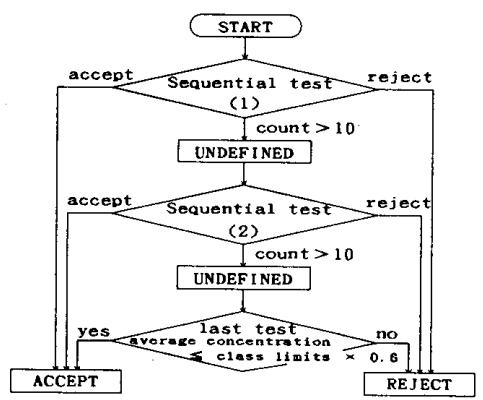

困一-9日本工業規格における逐次検定法の評価手順

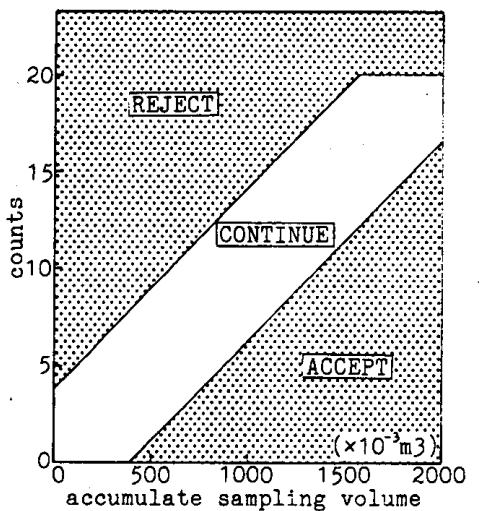

困-10 クーパーらによる逐次検定法の評価線図

次に、実際のクリーンルーム評価方法に準じた逐次検 定法のシミュレーションを行い、一測定点の評価特性を 信頼区間法（J I S）およびワルド応用法により検討し た。図ー11に、両評価法による合格判定確率と平均判定 所要時間を平均濃度およびその分布形に対して示す。ワ ルド応用法では、基準濃度付近において合格と判定され る確率が約 $50 \%$ に達し、判定所用時間は相対的にJ I S の評価法より短いことがわかる。

図 - 12 は平均濃度に対する J I S の評価方法の判定確 率を示したものである（ $\mathrm{k}=1 ）$ 。基準濃度付近におい て約 $70 \%$ 程度が最終検定に至っており、また最終検定に おいて合格と判定される確率は、概して10\%以下となっ ている。

平均濃度に対する合格判定確率を図 -13 に、平均判定 
所要時間を図ー14に示す（ $\mathrm{k}=1 ）$ 。J I Sによる正規 の評価方法（以下 J I S 正規法）に関しては、平均濃度 が上限濃度以下であった場合を合格としており、“2 回 の逐次検定で判定不能の場合、最終検定を行わずに不合 格の判定を下す”とした場合でも、判定確率はあまり変 わることなく大幅に判定所要時間が短縮され、最終険定 が平均判定所要時間に大きく影響することがわかる。ま たJ I S 正規法では、吸引流量 $3(\ell /$ min $)$ の粒子計数 器を使用したとすると約 33 時間の計測時間を必要とする か、逐次検定法を用いた評価方法は計測時間の短縮に有 効であるといえる。

図ー15は95\%の確率で合格及び不合格と判定される平 均濃度を示したものであるが、逐次検定法はJ I S 正規 法に比へて分布形の変化の影響が大きいことがわかる。
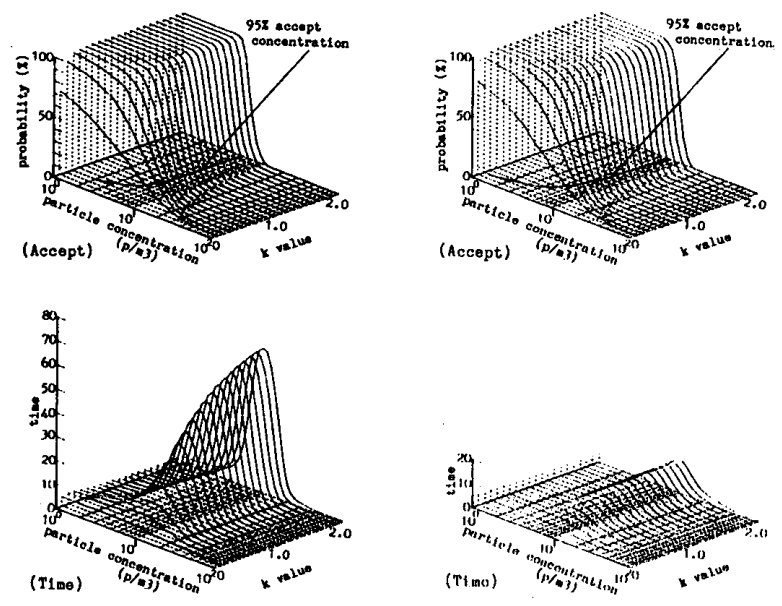

一日本工業规格 -

ーワルド法ー

図-11 平均濃度および分布形に対する

合格判定確率と平均所要時間

Sequential Test (1) Sequential Test (2) Last Test [J ACCEPT $D \triangle$ ACCEPT

ACCEPT

NYREJECT

REJECT

REJECT

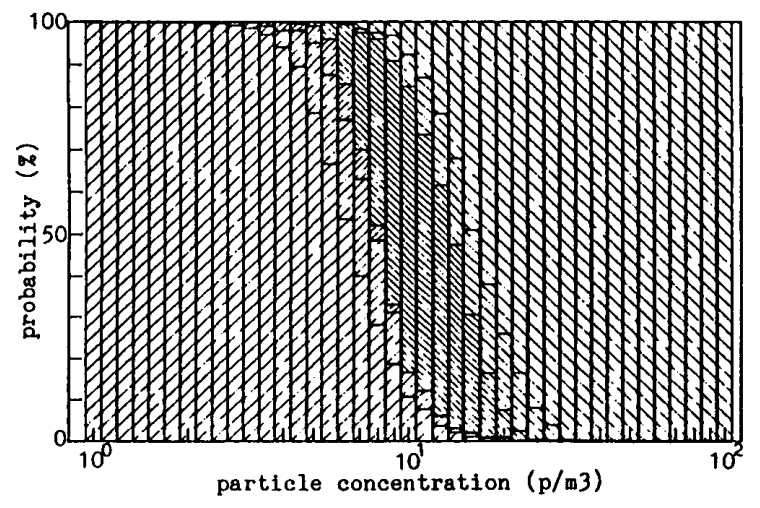

目-12 平均浱度に対する各判定確率（日本工業規格）
次に、逐次検定法を用いた評価方法及び J I S 正規法 による空間全体の評価特性を検討した。測定点を 6 点、 空間全体の粒子濃度が一様であると仮定し、各測定点に
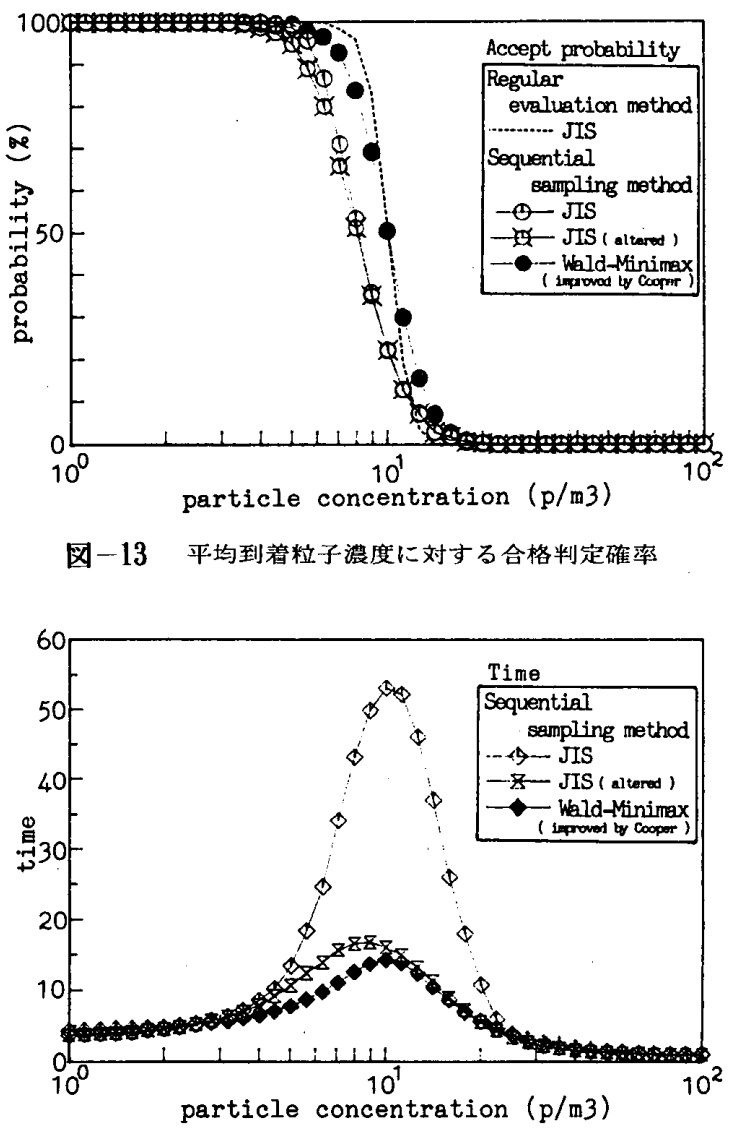

园-14 平均到着粒子搌度に対する平均判定所要時間

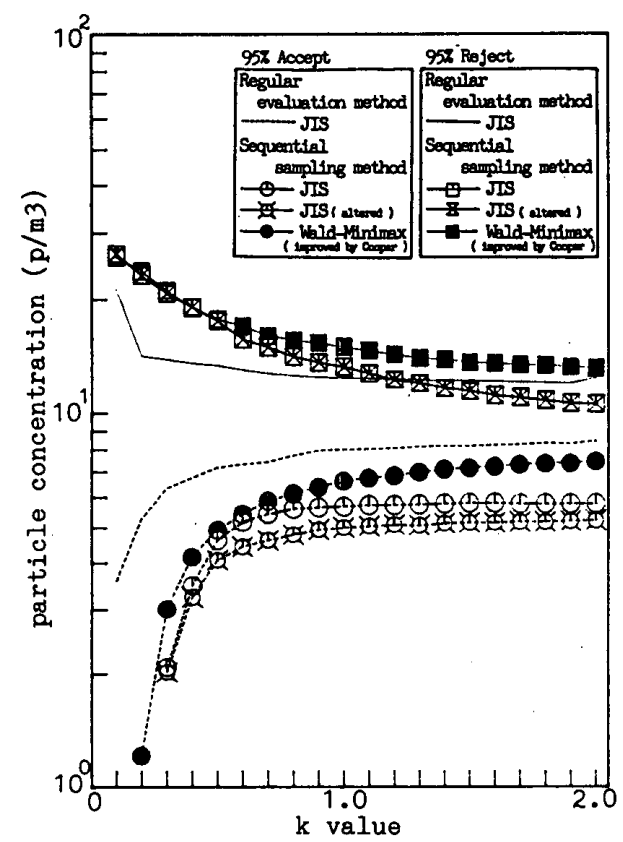

図-1595\%の確率で合格及び不合格となる 平均到着粒子浱度 
おける合格判定の確率を 6 乗することにより逐次検定法 の合格判定の確率を求めた。図ー 16 は $\mathrm{k}=1$ として、空 間全体の評洒において逐次検定法および正規評価法の平 均濃度に対する合格判定確率を示したもので、いずれの 評価方法によっても、クラス基準濃度以上の平均濃度に おいて合格と判定される確率はほぼ０となっている。図 - 17 に $95 \%$ の確率で合格および不合格と判定される平均 濃度を示す。両逐次検定評価法とも J I S 正規法より厳 しい安全侧の判定を下すことがわかる。

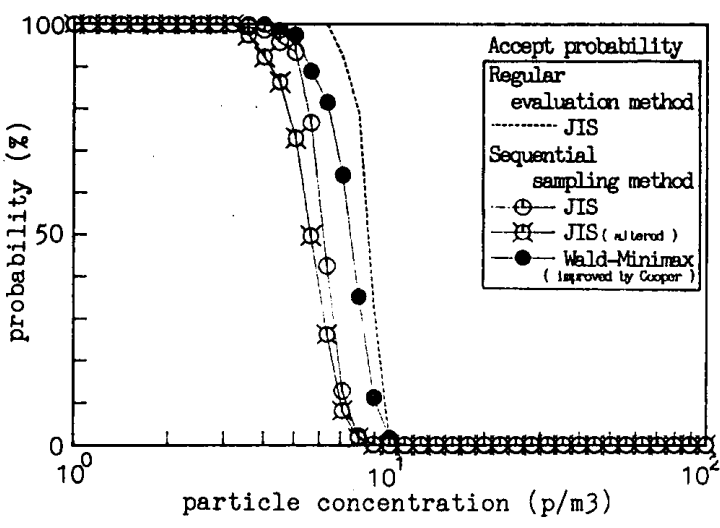

図-16平均到着粒子濃度に対する合格判定確率

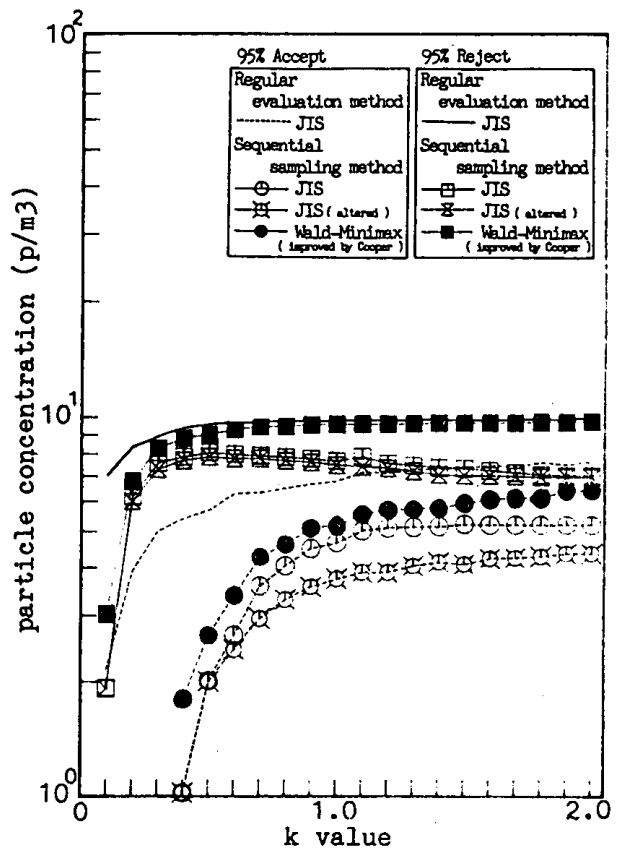

図-1795\%の確率で合格及び不合格と判定される 平均濃度 (空間全体)

\section{7.おわりに}

本研究では、モンテカルロ法によるシミュレーション に基づき、クリーンルームの清浄度評価におりる逐次検 定法の特性を把握しその有効性を確認した。本研究の成 果をまとめると以下の通りである。

(1) 粒子計数器に検出される粒子の到着分布シミュレ ーションモデルとして、一定時間粒子到着数モデルと粒 子到着間時間モデを設定し、モデルとしての特性を明 らかにした。

( 2 ）信頼区間法とワルドミニマックス法の平均到着粒 子濃度及びその分布形に対する清浄度評価特性を把握し た。

（3）光散乱式粒子計数器の偽計数の発生頻度分布を术 アソン分布とし清浄度評価への影響とともに、発生頻度 の許容上限值を示した。

（4）日本工業規格に規定されている逐次検定法及びク 一パーらにより提案されているワルドミニマックス法を 変形した評価法のクリーンルームの各測定点における空 間全体における評価特性をJ I S 正規法とともに比較し 明らかにした。

なお逐次検定法は、クリーンルームに限らず低濃度評 価に応用できるものと考えられ、今後他分野への応用も 望まれる。

\section{〈参考文献》}

1) 泉本利章他：スーパークリーンルームの確率論的清净度 評価, 第 4 回空気清浄とコンタミネーションコントロー 儿研究大会予稿集, PP. $99 \sim 104,1985$

2）日本規格協会：JIS B 9920, クリーンルームにおける浮 遊微粒子の濃度測定及びクリーンルームの空気清浄度の 評価方法, 1990

3）藤井修二他：クリーンルームの清净度評価における逐次 検定法の特性 その 1 モンテカルロ法のシミュレーショ ンモデル, 日本建築学会大会学術講演梗概集, PP. 689〜 690,1991

4）藤井修二他：クリーンルームの清浄度評価における逐次 検定法の特性 その 2 逐次検定法による測定点および空 間の評価, 日本建築学会大会学術講演梗概集, PP. 691〜 692,1991

5) D. W. Cooper : A Sequential Sampling Statistics for Evaluating Low Concentrations, Journal of the environmental science(Sep/0ct)1988

6) D. W. Cooper : A Sequential Sampling Plan for Federal Standard 209, Journal of the IES(Sep/0ct) 1990

(1993 年6月 10 日原稿受理, 1993 年 10 月 27 日採用決定) 